\title{
Set of Income Generating Factors of the Scheduled Tribes in Churachandpur District of Manipur
}

\author{
${ }^{1}$ Dr. N. Sharat Singh, ${ }^{2} \mathrm{Ph}$. Ngamkhokhai Mate \\ 1. Asst. Professor, Dept. of Statistics, Thoubal College (Manipur University, Imphal), \\ 2. Research Scholar, Department of Economics, Manipur University, Imphal
}

\begin{abstract}
A cross sectional as well as community based study is conducted during 7 months (August, 2011February, 2012) to identify the ways of income generation of the tribal communities residing in Churachandpur District of Manipur, the North Eastern Border States of India. Utilising a multiple regression analysis, the determinants of income generation can be detected to be educational status, road connectivity, family size, govt. employed family member, area of agricultural land and type of family. The present findings may be baseline information of the economic development in the study population.

Key words: family income, tribal community, education, agricultural land, road connectivity
\end{abstract}

\section{Introduction}

India is facing the problems of rural sectors which cover about $75 \%$ in its population. More than $90 \%$ of labour force is employed in unorganized sector having no social security and other benefits of employment as in the organised sector (Usha, 2007). The words 'poverty and rural sectors' are synonymous with tribal and backward communities in the country. The impacts of such poverty hits the women's life in tribal and backward communities they are facing the problems of social discrimination too. The situation is not an exception in Manipur.

With more than $8 \%$ of the total population, India has 258 scheduled tribes (Sinha, 2003). The tribes in Manipur have a unique feature for a large number of their dialects with least population. According to Census Report, the schedule tribes population is increased from 6.32 lakh in 1991 to 7.41 lakh in 2001 while the corresponding state's total figure is 18.37 lakh and 22.94 lakh and it touches 27.93 lakh in 2011 (DES, Government of Manipur, 2011). Residing mostly in the hill districts, the 33 scheduled tribes are recognized to be Aimol, Anal, Angami, Chiru, Chothe, Gangte, Hmar, Kabui, Kacha Naga, Koirao, Koireng, Kom, Lamgang, Mizo, Lushai, Maram, Maring, Mao, Monsang, Moyon, Paite, Ralte, Sema, Simte, Suhte, Tang Khul, Thadou, Vaiphei, Zou, Poumei Naga, Tarao, Kharam, and Kuki tribes. The Mao tribes are mostly concentrating in the Senapati district, the Kabui in the Tamenglong district, the Anals and Marings in the Chandel district and Thadou and Kuki in the Churachandpur district. The state's high differential socio-demographic figures between valley and hill areas also lead uncertainty in the socio-economic development plans say for instance, the decennial population growth rate is still raised from $32.38 \%$ in $1981-91$ to $35.46 \%$ in $1991-2001$ in hill districts but the corresponding figures is observed to be $27.65 \%$ to $19.04 \%$ in valley districts while the state's figure falls from $29.29 \%$ to $24.86 \%$.

\section{Literature Review}

The socio-economically discriminated women are facing various types of obstacles for empowerment (Sen, 2001). In their study conducted in Karnataka data, Puttaraja and Heggade (2012) highlighted that economic independence and education of tribal women will go a long way in attaining self-reliance for women. Having low educational status, such tribal communities generate their income mostly from agro-based, household based activities such as dairying, fisheries, small animal husbandry, handlooms, handicraft, social forestry and sericulture. In their findings, Dewangan et al. (2011) observed the tribes in Raigarh District of Chhattisgarh could generate additional income from sericulture.

In spite of so much emphesise given to tribal communities since 60 years of independence and more than half century of plan interventions with a good number of provisions, Indian tribe is nowhere near a satisfactory solution. In a recent study, it is found that the socio-economic status of tribes in Jharkhand centers one of the deprivation rather than development (Roy, 2012). The high incidence of rape cases and domestic violence are associated with women disempowerment which causes a source of economic poverty. In his finding, Bulender (2000) highlighted that poorer women are often raped in abusive relationship due to their dependence on partner for food, shelter and money. Awais et al. (2009) also pointed out that tribal women face problems and challenges in getting a sustainable livelihood and a decent life due to the environmental degradation and the interferences of the outsiders. They further observed that without any healthy and 
productive tribal women, the tribal societies can not have productive settled agriculture in the sense that tribal women contribute immensely to the agriculture.

\section{Objectives}

The objective of the present study is to identify empirically the factors or so called sectors of income generation of the tribal communities residing in Churachandpur District of Manipur, India.

\section{Materials and Methods}

Under 'stratified random sampling', a sample of 708 household were surveyed in cross sectional mode in Churachandpur, one of the four hill districts of Manipur by using a 'pre-tested and semi-structural schedule' as tool. The sample survey was completed during 7 months (August, 2011 - February, 2012). Applying multiple regression analysis, a best set of co-variates for income generating sectors has been explored in the study population through SPSS vs19. To quantify some qualitative variables, binary dummy variable $(0,1)$ technique is used and 0.4 is also taken as the cut off zero-order correlation value for scanning the multicollinearity problems among the co-variates. While interpreting the results that is the effects of the factors on income levels, the regression coefficient $(\beta)$ with its $95 \%$ confidence interval $(\mathrm{CI})$ and $\mathrm{P}$-values of the t-test for the coefficients are used. In the present analysis, the levels of significance have been advocated by $5 \%(\mathrm{P}<0.05)$ as statistical significance and $1 \%(\mathrm{P}<0.01)$ as highly significance.

Functional relationship - The per capita income of a family $(Y)=f$ (cultivable land area, number of family members, number of family members engaged in agriculture and allied activities, number of government employed family member, road connectivity, type of family, educational status, social class and female age at marriage).

Variable specification - In this analysis the response variable is considered to be the average annual income per family measured in terms of rupees. It is termed as per capita income of a family. The improvement level in the per capita income is assumed to be functionally related with only nine predictors of interest. They are the area of agricultural or cultivable land (in hectare); number of family members; number of family members engaged in agriculture and allied activities; number of government employed family member; road connectivity as infrastructure variable which is defined as the distance (in $\mathrm{km}$ ) of the residence of the respondent from nearest town; type of family ( 1 if joint and 0 , otherwise that is nuclear); educational status as quantified by the number of family members who are of twelve standard and above; social class (1if Kuki consisting of Gangte, Thadou, Hmar, and Kom; 0 if Zoumi consisting of Paite, Vaiphei, Zou, Simte, and others). Due to many similar characteristics, the classification (Kuki/ Zoumi) of social structure is made for present analysis purpose only. As socio-demographic variable, female age at marriage is also included in the set of explanatory variables. The logic of the inclusion of socio-demographic factor like female age at marriage is thought to be related with economic development of a society.

Hypothesis - The null hypothesis $\left(H_{0}\right)$ of the present analysis may be spelt out as $H_{0}: \beta_{i}=0$, each regression coefficient is zero. In other words, the per capita income of a family is not influenced by their nine socio-economic characteristics as against the alternative hypothesis $\left(H_{l}\right)$, pronounced by $H_{l}: \beta_{i} \neq 0$ that is the per capita income of a family is significantly influenced by the characteristics of the family under study.

\section{Analysis and Results}

Multiple regression analysis - In the present multiple regression analysis, the per capita income of family under study that is the annual income per family is functionally related with nine explanatory variables of interest. Using the zero order correlation matrix, the problem of multicollinearity is scanned and controlled at $r$ $=0.4$ depicted in Table -1 . For categorical variables, the regression coefficients are computed by utilizing binary dummy variable $(0,1)$ for easier way of interpretation. It is evident that the null hypothesis is rejected in the sense that all regression coefficients $\left(\beta_{i}\right)$ can not be zero indicating that some of the explanatory variables have significant impacts on the per capita income of family under study. It is evidenced by F-value of the regression model say $28.13(\mathrm{P}<0.01)$. In this analysis, the total variation in the per capita income of family has been explained about $40 \%$ by the explanatory variables or so called predictors $\left(R^{2}=0.379\right)$.

The six out of nine variables are confirmed to have their significant contributions on the variation of per capita income in population. They are agriculture or cultivable land area $(\mathrm{P}<0.01)$, number of family members $(\mathrm{P}<0.01)$, number of family members engaged in agriculture and allied activities, number of government employed family member $(\mathrm{P}<0.01)$, road connectivity $(\mathrm{P}<0.01)$, type of family $(\mathrm{P}<0.05)$, and educational status $(\mathrm{P}<0.01)$. After adjusted the joint effects of other eight variables, area of agriculture/ cultivable land has positive influence on the family's annual income in the sense that about rupees three thousand can be increased in the per capita income of a family as increment of one hactre of cultivable land of 
the family as quantified as $\beta=2933$ (95\%CI: 1038-4828, $\mathrm{P}<0.01$ ). As per increment of one government employee in a family, the per capita family income will correspondingly be enhanced by Rs. 5357 ( $\beta=5357$ with 95\%CI: 2929-7784; $\mathrm{P}<0.01$ ). This significance effect may be interpreted that government employment significantly influences on the advancement of family income. Education and type of family have also been found to have their positive association with the improvement of the income level when controlled the joint effects of other variables.

But, the annual family income is negatively associated with the number of family member ( $\beta=-5123$, $\mathrm{P}<0.01$ ) and the distance of the place of residence from the main market or town as the road connectivity (in $\mathrm{km})$ under the caption of infrastructure $(\beta=-3313, \mathrm{P}<0.01)$. In crude sense, it may be interpreted that the annual family income can not be improved with higher fertility of the respondent. Also under infrastructure aspect, the per capita income has been reduced by at least rupees three thousand as per increment of one kilometer in the road connectivity under study $(\beta=-3313, \mathrm{P}<0.01$ ). As such the multiple regression model on the per capita income ( $Y$ in rupees) of family may be expressed as:

$Y=52360+2933$ (cultivable land area) - 5123(number of family member) - 861(number of family members engaged in agricultural and allied activities) +5357 (number of govt. employed family member) - 3313(distance of road connectivity in $\mathrm{km})+1850($ social class; Kuki=1, Zoumi $=0)+$ 9019(type of family; joint $=1$, nuclear $=0)+7318$ (educational status, number of family members who are at least twelve standard and above) - 199(female age at marriage).

Stepwise regression analysis - To explore the best set of predictors or so termed the important determinants of the variation in the per capita income in the population, the model is further analysed by using stepwise regression method. The analysis is carried out in six steps say from Model 1 to Model 6 (Table - 3). It reveals that lastly six predictors have significant contribution on average annual income of the family in the population. They are observed to be educational status, distance of road connectivity (in $\mathrm{km}$ ), number of family member, number of govt. employed family member, area of cultivable/ agricultural land (in hac.), type of family. Only two factors - distance of road connectivity and number of family member are having negative impact on per capita income and four other variables are positively associated with per capita income in the population. These six predictors explain $36 \%$ of the total variation in the per capita income $\left(\mathrm{R}^{2}=0.358\right)$.

From the model 6, levels of contribution of the six predictor variables can be assessed. To each increase of family member who are qualified for $12^{\text {th }}$ standard and above educational qualification, the per capita income of the family will highly significantly be improved $(\mathrm{P}<0.01)$ by Rs. 7283 (95\%CI: 5399-9167) while keeping constant the joint effects of other five variables under study. Also, each increase of one government employee in a family, the per capita income of the family will be significantly improved by Rs. 5369. Despite, Rs. 5061 will be significantly reduced $(\mathrm{P}<0.01)$ in per capita income to each increment of one member in the family. It may also be noted in the last model, Rs. 8409 is the level of improvement in per capita income of a joint family $(\mathrm{P}<0.05)$ rather than that of nuclear family when the joint effects of other five variables are held constant. This improvement in the income level is observed to be statistically significant at 0.05 probability level of significance. The last fitted model is also found to be significant and efficient as its regression diagnostics say $\mathrm{F}=41.79(\mathrm{P}<0.01)$ and Durbin-Watson Statistic, 1.79 which is closed to 2 . The model F-value changes from $107.84(\mathrm{P}<0.01)$ in model-1 to $41.79(\mathrm{P}<0.01)$ in the last model (6). The corresponding $R^{2}$-value is observed to be advancing from $13 \%$ in the first model to $36 \%$ in the last model. A monotonic improvement in the degree of explanation of per capita income is also observed to be $23 \%$ from the Model 1 to the last Model 6.

The six factors in the last model 6 may be treated as the elements of the best set of covariates or determinants of per capita income in the population. Among these, educational status is the most influential $(\mathrm{t}=7.58, \mathrm{P}<0.01)$ shown in Table - 3. Its coefficient, 7283 (95\%CI: 5399-9167) stresses as the positive increase in the per capita income of family when such an educated of at least $12^{\text {th }}$ standard increase in the family members while the linear effects of other five factors are controlled typically. In this way, three other variables viz., number of government employed family member $(\mathrm{P}<0.01)$, area of cultivable/ agricultural land $(\mathrm{P}<0.01)$ and type of family $(\mathrm{P}<0.05)$ have also been confirmed to have their positive impacts on family income. However, distance of road connectivity $(\beta=-3475 ; \mathrm{t}=5.64, \mathrm{P}<0.01)$ and number of family member $(\beta=-$ $5061 ; \mathrm{t}=6.76, \mathrm{P}<0.01)$ are having negative influences on the family income level say family's per capita income. Thus the last best fitted regression model on family's per capita income ( $Y$ in rupees) in the population is observed to be:

$Y=47804+7283$ (educational status) - 475(distance of road connectivity) - 5061(number of family member $)+5309$ (number govt. employed family member) +2424 (cultivable land area) +8409 (type of family). 


\section{Discussion and Conclusion}

From the present empirical and interpretative analysis, the six sectors - education $(\mathrm{P}<0.01)$, road connectivity $(\mathrm{P}<0.01)$, number of family member $(\mathrm{P}<0.01)$, number of government employed family member $(\mathrm{P}<0.01)$, area of cultivable or agricultural land $(\mathrm{P}<0.05)$, and type of family $(\mathrm{P}<0.05)$ can be identified to be determinants of the income generation of the tribal communities in Churachandpur District of Manipur (India). The lack of good road connectivity and larger number of family members which is assumed to be high fertility are reducing the income level of the communities. Despite, educational level of at least $12^{\text {th }}$ standard, number of government employee in the household and larger cultivable land area can enhance the income levels of the community. The significant positive association between educational level and economic status of tribal communities is in agreement with the similar views of Tungdin and Kapoor (2010) and Puttaraja and Heggade (2012). Also, the views of larger cultivable land enhances the economic status of tribal people is supported by the findings of Dewangan et al., (2011). It indicates that the socio-economic status of tribal communities may be solely dependent of agriculture and allied activities. Thus, to achieve the millennium development goals subject to the welfare of tribal economy, the government and other agencies have to promote education, good road connectivity, population control, and safe agriculture land from the large scale development projects covering vast agricultural areas specifically in hill districts of Manipur.

\section{References}

[1]. Awais, M., Tosib, A. and Mohd, A., 2009, Socioeconomic empowerment of tribal women: An Indian perspective. International Journal of Rural Studies; 16(1): 1.

[2]. Budlender, D., 2000, Human development. In: J May (Ed.): Poverty and Inequality in South Africa: Meeting the Challenge. Cape Town: David Philip, pp. 98-139.

[3]. Dewangan, S. K., Sahu, K. R., Achari, K. V. and Soni, S., 2011, Socio-economic empowerment of tribal women through sericulture: A study of Lailunga Block of Raigarh District, Chhattisgarh, India, International Journal of Business and Management; 6(12): 297302.

[4]. Directorate of Economics and Statistics (DES), Government of Manipur, 2011, Economic Census Manipur '2010-2011', p. 15.

[5]. Puttaraja, A. and Heggade, O. D., 2012, Economic empowerment of tribal women in Karnataka: A case study in Mysore and Chamarajanagara District. Studies of Tribes and Tribals; 10(2): 173-181.

[6]. Roy, D., 2012, Socio-economic status of schedule tribes in Jharkhand. Indian Journal of Spatial Science; 3(2): 26-34.

[7]. Sen, A. K., 2001, Many faces of gender inequalities. Public Lecture Delivered at Radcliff Institute at Harvard University. Frontline; 18(22); Oct, 27 - Nov., 09

[8]. Sinha, B. R., 2003, Forest Politics and Tasar Culture. A paper presented at the Workshop held at Dehradun (India) on the $10^{\text {th }}$ April, 2003.

[9]. Tungdim, M. G. and Kapoor, S., 2010, Gender differentials in tuberculosis: impact of socio-economic and cultural factors among the tribals of North East India. The Open Social Science Journal; 3: 68-74.

[10]. Usha, R. J., 2007, Employment generation to women in drought prone areas: A study with reference to the development of sericulture in Anantpur District of Andhra Pradesh.

Table - 1

Correlation Matrix among the quantitative independent variables

\begin{tabular}{|c|c|c|c|c|c|c|c|}
\hline Variables & 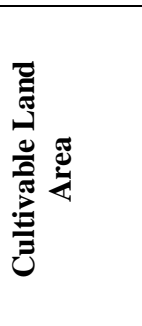 & 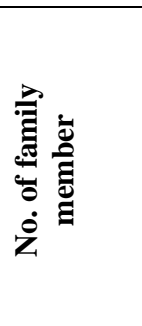 & 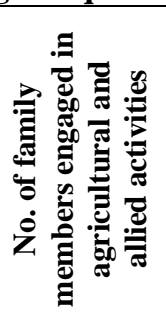 & 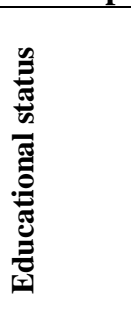 & 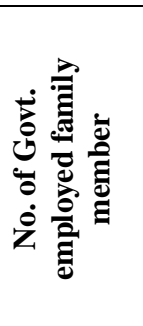 & 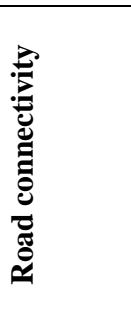 & 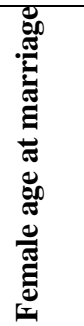 \\
\hline $\begin{array}{l}\text { Cultivable Land } \\
\text { Area }\end{array}$ & 1.000 & & & & & & \\
\hline $\begin{array}{l}\text { No. of family } \\
\text { member }\end{array}$ & $0.108 * *$ & 1.000 & & & & & \\
\hline $\begin{array}{l}\text { No. of family } \\
\text { members engaged in } \\
\text { agricultural and } \\
\text { allied activities }\end{array}$ & $0.401 * *$ & $0.256^{* *}$ & 1.000 & & & & \\
\hline Educational status & $0.169 * *$ & 0.055 & 0.035 & 1.000 & & & \\
\hline $\begin{array}{l}\text { No. of Govt. } \\
\text { employed family } \\
\text { member }\end{array}$ & -0.051 & 0.032 & 0.012 & $0.355 * *$ & 1.000 & & \\
\hline Road connectivity & $0.145 * *$ & -0.058 & $0.190^{* *}$ & 0.020 & $-0.178 * *$ & 1.000 & \\
\hline $\begin{array}{l}\text { Female age at } \\
\text { marriage }\end{array}$ & $0.162 * *$ & $-0.173^{* *}$ & $0.087 *$ & $0.193 * *$ & 0.068 & $0.224 * *$ & 1.000 \\
\hline
\end{tabular}

**Correlation is significant at the 0.01 level *Correlation is significant at the 0.05 level 
Table - 2

Multiple regression coefficients and their test values

\begin{tabular}{|l|c|c|}
\hline \multicolumn{1}{|c|}{ Variables } & $\beta(\mathbf{9 5 \%} \mathbf{C I})$ & t-value \\
\hline (Constant) & $52360(35677,69043)$ & $6.16(\mathrm{P}<0.01)$ \\
\hline Area of cultivable/ agricultural land (in hac.) & $2933(1038,4828)$ & $3.04(\mathrm{P}<0.01)$ \\
\hline No. of family member & $-5123(-6654,-3591)$ & $-6.57(\mathrm{P}<0.01)$ \\
\hline $\begin{array}{l}\text { No. of family members engaged in agricultural and allied } \\
\text { activities }\end{array}$ & $-861(-2292,571)$ & $-1.18(\mathrm{P}>0.05)$ \\
\hline No. of Govt. employed family member & $5357(2929,7784)$ & $4.33(\mathrm{P}<0.01)$ \\
\hline Distance of road connectivity (in km) & $-3313(-4539,-2088)$ & $-5.31(\mathrm{P}<0.01)$ \\
\hline Social Class & $1850(-3569,7269)$ & $.670(\mathrm{P}>0.05)$ \\
\hline Type of family & $9019(913,17125)$ & $2.19(\mathrm{P}<0.05)$ \\
\hline Educational status & $7318(5395,9241)$ & $7.47(\mathrm{P}<0.01)$ \\
\hline Female age at marriage & $-199(-775,375)$ & $-0.68(\mathrm{P}<0.05)$ \\
\hline
\end{tabular}

Model Diagnostics: $F=28.13(P<0.01) ; R^{2}=0.379$, Durbin-Watson $=1.89$

Table - 3

Stepwise regression coefficients and their test values

\begin{tabular}{|c|c|c|c|c|}
\hline Step & Variables & $\beta(95 \% \mathrm{CI})$ & t-value & Model Diagnostics \\
\hline \multirow[t]{2}{*}{1} & (Constant) & $18184(14359,22009)$ & $9.33(\mathrm{P}<0.01)$ & \multirow{2}{*}{$\begin{array}{l}\mathrm{F}=107.84(\mathrm{P}<0.01) \\
R^{2}=0.133\end{array}$} \\
\hline & Educational status & $9755((7911,11599)$ & $10.38(\mathrm{P}<0.01)$ & \\
\hline \multirow[t]{3}{*}{2} & (Constant) & $27982(23406,32558)$ & $12.01(\mathrm{P}<0.01)$ & \multirow{3}{*}{$\begin{array}{l}\mathrm{F}=83.18(\mathrm{P}<0.01) \\
R^{2}=0.192\end{array}$} \\
\hline & Educational status & $8626(6817,10435)$ & $9.36(\mathrm{P}<0.01)$ & \\
\hline & Distance of road connectivity (in km) & $-4286(-5466,-3106)$ & $-7.13(\mathrm{P}<0.01)$ & \\
\hline \multirow[t]{4}{*}{3} & (Constant) & $47296(39827,54765)$ & $12.43(\mathrm{P}<0.01)$ & \multirow{4}{*}{$\begin{array}{l}\mathrm{F}=71.86(\mathrm{P}<0.01) \\
R^{2}=0.235\end{array}$} \\
\hline & Educational status & $9039(7273,10804)$ & $10.05(\mathrm{P}<0.01)$ & \\
\hline & Distance of road connectivity (in km) & $-3842(-4999,-2685)$ & $-6.52(\mathrm{P}<0.01)$ & \\
\hline & No. of family member & $-4014(-5260,-2768)$ & $-6.32(\mathrm{P}<0.01)$ & \\
\hline \multirow[t]{5}{*}{4} & (Constant) & $46392(38994,53790)$ & $12.31(\mathrm{P}<0.01)$ & \multirow{5}{*}{$\begin{array}{l}\mathrm{F}=59.36(\mathrm{P}<0.01) \\
R^{2}=0.294\end{array}$} \\
\hline & Educational status & $7765(5917,9614)$ & $8.25(\mathrm{P}<0.01)$ & \\
\hline & Distance of road connectivity (in km) & $-3456(-4614,-2297)$ & $-5.85(\mathrm{P}<0.01)$ & \\
\hline & No. of family member & $-4102(-5335,-2869)$ & $-6.53(\mathrm{P}<0.01)$ & \\
\hline & No. of Govt. employed family member & $5067(2650,7484)$ & $4.12(\mathrm{P}<0.01)$ & \\
\hline \multirow[t]{6}{*}{5} & (Constant) & $45662(38268,53055)$ & $12.12(\mathrm{P}<0.01)$ & \multirow{6}{*}{$\begin{array}{l}\mathrm{F}=49.07(\mathrm{P}<0.01) \\
R^{2}=0.326\end{array}$} \\
\hline & Educational status & $7239(5350,9127)$ & $7.52(\mathrm{P}<0.01)$ & \\
\hline & Distance of road connectivity (in km) & $-3763(-4943,-2583)$ & $-6.26(\mathrm{P}<0.01)$ & \\
\hline & No. of family member & $-4218(-5450,-2986)$ & $-6.72(\mathrm{P}<0.01)$ & \\
\hline & No. of Govt. employed family member & $5341(458,3906)$ & $4.33(\mathrm{P}<0.01)$ & \\
\hline & $\begin{array}{l}\text { Area of cultivable/ agricultural land (in } \\
\text { hac.) }\end{array}$ & $2182(458,3906)$ & $2.48(\mathrm{P}<0.05)$ & \\
\hline \multirow[t]{7}{*}{6} & (Constant) & $47804(40151,55458)$ & $12.26(\mathrm{P}<0.01)$ & \multirow{7}{*}{$\begin{array}{l}\mathrm{F}=41.79(\mathrm{P}<0.01) \\
R^{2}=0.358 \\
\text { Durbin-Watson=1.89 }\end{array}$} \\
\hline & Educational status & $7283(5399,9167)$ & $7.58(\mathrm{P}<0.01)$ & \\
\hline & Distance of road connectivity (in km) & $-3475(-4683,-2266)$ & $-5.64(\mathrm{P}<0.01)$ & \\
\hline & No. of family member & $-5061(-6528,-3593)$ & $-6.76(\mathrm{P}<0.01)$ & \\
\hline & No. of Govt. employed family member & $5309(2896,7722)$ & $4.32(\mathrm{P}<0.01)$ & \\
\hline & $\begin{array}{l}\text { Area of cultivable/ agricultural land (in } \\
\text { hac.) }\end{array}$ & $2424(689,4160)$ & $2.74(\mathrm{P}<0.05)$ & \\
\hline & Type of family & $84089(398,16419)$ & $2.06(\mathrm{P}<0.05)$ & \\
\hline
\end{tabular}

